História 



\title{
A evolução constitucional do Brasil
}

\author{
PAULO BONAVIDES
}

$\mathrm{T}$ RAÇANDO a evolução constitucional do Brasil devemos concentrar todo o interesse indagativo e toda a diligência elucidativa numa seqüência de peculiaridades, de ordem histórica e doutrinária, que acompanharam e caracterizaram o perfil das instituições examinadas, designadamente com respeito à concretização formal e material da estrutura de poder e da tábua de direitos cujo conjunto faz a ordenação normativa básica de um Estado de poderes limitados.

De tal sorte que a reflexão há de ocorrer ao redor de temas-chave como poder constituinte e Constituição, separação de poderes, organização unitária e organização federativa do Estado e direitos do homem, cuja universalidade e fundamentalidade, por exprimir parte essencial de todo pensamento político concretizado em termos constitucionais, não pode deixar de ser assinalado com todo o destaque devido.

O Brasil desta análise histórica corresponde assim a um modelo de país constitucional que até aos nossos dias se busca construir, numa longa travessia de obstáculos.

Até agora esse modelo permanece todavia inacabado, após cerca de dois séculos de renovadas diligências e sacrifícios; é projeto fugaz sujeito às oscilações da idéia e da realidade com as quais não logrou ainda se compatibilizar. Projeto bloqueado inumeráveis vezes pelas resistências absolutistas, pelo continuísmo e vocação de perpetuidade governista, bem como pelos interesses representativos comprometidos com um status quo de dominação que a classe política busca manter inalterável, debaixo de seu jugo, insensível por inteiro ao rápido senão vertiginoso agravamento das desigualdades sociais e regionais, cujo quadro é sobressaltante enquanto prelúdio de uma tragédia de sangue e guerra civil, de conseqüências imprevisíveis.

Vemos iminentes, na senda da política recolonizadora em execução, as batalhas de emancipação do segundo período colonial de nossa História.

Mas essas batalhas hão de ferir-se unicamente se tivermos fibra, coração e alma para arrostar, com as energias do espírito nacional, rememorativo 
das páginas heróicas do passado, a soberba imperialista dos invasores silenciosos, que ora nos ameaçam dissolver a identidade de povo, apagando os traços, as cores e as raízes de nossa cultura, ou seja, de nossa brasilidade.

O constitucionalismo europeu teve por premissa de luta e contradição o absolutismo de uma sociedade já organizada e estruturada, a saber, a sociedade feudal do ancien régime. Tinha história e tradição. Tinha riqueza e cultura. Tinha profundas raízes espirituais

O nosso constitucionalismo, ao revés, levantou-se sobre as ruínas sociais do colonialismo, herdando-lhe os vícios e as taras, e ao mesmo passo, em promiscuidade com a escravidão trazida dos sertões da África e com o absolutismo europeu, que tinha a hibridez dos Braganças e das Cortes de Lisboa, as quais deveriam ser o braço da liberdade e todavia foram para nós contraditoriamente o órgão que conjurava a nossa recaída no domínio colonial.

Sem embargo desses pressupostos negativos, que significaram desníveis qualitativos de iniciação constitucional, tanto de portugueses quanto de brasileiros, houve um processo até certo ponto comum de introdução de instituições representativas e constitucionais no que toca à velha metrópole e à nascente nacionalidade, quando esta estreou os primeiros passos da caminhada para a independência imperial e a criação do Estado.

Com efeito, a fonte doutrinária fora a mesma: o constitucionalismo francês, vazado nas garantias fundamentais do número 16 da Declaração dos Direitos do Homem e do Cidadão de 26 de agosto de 1789. Nesse documento se continha a essência e a forma inviolável de Estado de Direito. Idêntica, por igual, a fonte positiva de inspiração imediata: a Constituição de Cadiz. Fomos tão longe que lhe decretamos a vigência durante 24 horas. Com efeito, entre nós o fraco rei espavorido a outorgou no Rio de Janeiro num triste episódio que mal recomenda a memória política de D. João VI.

A Constituição de Cadiz fora deveras relevante em determinar as bases liberais da primeira Carta Magna de Portugal: a chamada "Constituição vintista" de 23 de setembro de 1822 .

O influxo europeu, inglês e continental sobre o constitucionalismo brasileiro é traço marcante dos primeiros momentos de definição do nosso estatuto institucional.

As antigas colônias hispânicas recém-emancipadas ou em processo de emancipação, ao contrário, rompiam com o passado europeu, ou seja, com o velho mundo, deixando de consagrar assim as instituições da liberdade 
derivadas do mundo inglês ou francês para recolherem e adotarem a grande sugestão republicana, federativa e presidencial de Filadélfia, que seus constituintes lhes sopravam; mas fracassaram por inteiro criando repúblicas fragmentadas, federações desfeitas e governos presidenciais dissolvidos em ditaduras de opressão e caudilhismo.

Só com o advento da república cerca de 70 anos depois é que o Brasil mudava o norte de sua navegação política e aportava no mesmo modelo malogrado das repúblicas vizinhas.

A primeira época constitucional do Brasil, já nos seus primórdios, já na sua trajetória ao longo do Primeiro Reinado, guarda estreitos vínculos com Portugal, redundando numa singular comunhão de textos constitucionais, produto da mesma outorga imperial nos dois países: no Brasil, a Constituição de 1824; em Portugal, a Carta de 1826, cópia daquela que D. Pedro nos concedera e que ele fez chegar à Regência de Lisboa pelas mãos do embaixador inglês.

Foi, diga-se de passagem, um texto, em matéria de limitação de poderes, relativamente bem sucedido, tanto lá quanto aqui, não obstante o seu baixo grau teórico de legitimidade e suas discrepâncias com a inteireza democrática e representativa do século revolucionário que proclamara os direitos do homem e sagrara a inviolabilidade constitucional da separação de poderes.

A linha originalíssima das nossas nascentes constitucionais se enraíza em fatos históricos que, de início, acompanham os dois povos, decidem-lhe o destino e fazem depois ambos perseverarem na busca de um denominador comum das aspirações nacionais que é o Estado de Direito em toda a sua amplitude e solidez; um objetivo no caso brasileiro ainda por alcançar, decorridos já cerca de 200 anos de malogros institucionais, por obra de uma crise constituinte, instaurada ao começo da nacionalidade e recorrente em distintas ocasiões históricas, fazendo assim instável a base do regime político e jurídico, à míngua de elementos valorativos e espirituais suscetíveis de consolidar a ordem normativa da Constituição.

Antes de passarmos revista àqueles fatos históricos, obedecendo a uma seqüência já estabelecida - poder constituinte, separação de poderes, organização federativa e direitos fundamentais - faz-se mister a remissão ao item 16 da Declaração de Direitos do Homem e do Cidadão, onde se lê, em síntese, que é monumento de universalidade e precisão conceitual o programa constitucional da segurança jurídica, da liberdade e da contextura dos direitos fundamentais, conforme eles se vão positivando cumulativa- 
mente em distintas dimensões, sem se arredarem todavia do pedestal onde primeiro foram erguidos e sobre o qual assentam o equilíbrio e a certeza de sua continuidade e consistência.

É enorme - temos assinalado inumeráveis vezes - a importância daquele texto que, trasladado da Declaração de 1789 e incorporado na Constituição francesa de 1791, conserva em nossos dias de globalização, neoliberalismo, liberdades comprimidas e conculcadas, impressionante atualidade. Vale por dogma de todo Estado que garante direitos e separa poderes, configurando na substância e na essência a correta e perfeita imagem do Estado de Direito. Reza o texto, dantes programático, doravante normativo, depois de perpassar todas as idades constitucionais como farol que iluminava e guiava os navegantes da liberdade: "Toute societé dans laquelle la garantie des droits n'est pas assurée ni la séparation des pouvoirs determiné, n’a point de constitution.”

O constitucionalismo tem sido a grande jornada do pensamento político e de sua criatividade institucional buscando concreção no ordenamento dos povos que se sentem vocacionados para os regimes e governos da legitimidade democrática e representativa.

Traçar-lhe a trajetória só é possível com os olhos fitos na garantia dos direitos fundamentais de todas as gerações já conhecidas: primeira, segunda, terceira e quarta, e na separação de poderes que tanto incomodam contemporaneamente os arautos do absolutismo e os usufrutuários da autocracia, insubmissos às regras do Estado de Direito.

Em rigor, o constitucionalismo brasileiro não tem um ponto de partida autônomo. Em sua primeira fase, buscando-lhe, portanto, as origens, vamos encontrá-lo inapartavelmente vinculado aos sucessos políticos da velha metrópole. Segue assim um processo que faz mais inteligível e verídico versar o tema debaixo da designação de constitucionalismo luso-brasileiro até sua separação se tornar mais nítida com o fim do Segundo Reinado.

O período de 1808, ano da trasladação da Corte portuguesa ao Brasil, até 1824, data da outorga da Carta do Império, insere episódios constitucionais de suma importância tanto em Portugal quanto no Brasil. Em ambos, a idéia de Constituição e poder constituinte traz o sopro e a vibração das comoções revolucionários do século XVIII. Faz parte efetiva daquele momento de crise existencial que os dois países atravessavam: um porfiando por sobreviver, o outro por emergir como povo e nação.

Portugal e Brasil eram ao mesmo passo duas contradições da História. Com efeito, os princípios de liberdade circulavam nos dois países, mas o 
quadro político em ambos se apresentava singularmente confuso e contraditório conforme veremos.

Em Portugal a invasão e a ocupação pelo exército de Junot feriam o brio nacional, eram impopulares e provocavam reação armada, mas nem por isso a causa francesa, cifrada nos axiomas da Revolução, deixava de receber a simpatia e o apoio de uma vanguarda liberal que comungava com princípios e idéias de renovação institucional.

Desse grupo partiu em 23 de maio de 1808 a "Súplica” de Constituição a Napoleão Bonaparte; o primeiro documento de aspiração constitucional de língua portuguesa ou, como refere Canotilho, o primeiro "texto sistematizado em jeito de proposta de uma Constituição para Portugal" (J.J. Gomes Canotilho, “As Constituições”. In: José Mattoso, direção, História de Portugal, v. V, p.149).

Diz o insigne constitucionalista de Coimbra que os "suplicantes" não impetravam propriamente a convocação de um poder constituinte da nação senão que se contentavam com uma simples "outorga", uma "carta doada", algo à semelhança da Constituição outorgada por Napoleão ao GrãoDucado de Varsóvia, enfim, um apelo à introdução de formas representativas e princípios de igualdade civil e fiscal, bem como do axioma da igualdade de todos perante a lei no corpo e na estrutura do Estado.

A "Súplica” queria também uma sociedade com liberdade de imprensa, liberdade de cultos e fomento da instrução pública. Foi a primeira semente do constitucionalismo português, antecipando a ação das correntes do pensamento liberal que desembocaram na conspiração de Gomes Freire em 1817, na Revolução do Porto de 1820 e finalmente na Constituição de 1822, obra das Cortes de Lisboa, as quais tiveram, ao princípio, a presença e a colaboração dos deputados brasileiros, cuja dissidência abriu depois caminho à ruptura definitiva dos laços que podiam ainda conduzir a uma projetada união política do Brasil com Portugal.

As Cortes procederam porém de forma hostil aos interesses da nossa emancipação, seguindo política reacionária e desastrosa que levantava a suspeita de estar em curso de execução um plano de recaída nossa no estado colonial.

Se as raízes do constitucionalismo português estavam na "Súplica" a Bonaparte, as nossas se entranhavam no solo da Revolução Pernambucana de 1817, de marcante inspiração republicana. Tinham aliás um significado constitucional mais profundo, colocando diretamente em pauta a questão do poder constituinte com extrema clareza e determinação. Tanto pela na- 
tureza do movimento, confessadamente separatista e emancipativo, quanto pelos princípios que o inspiravam, todos derivados da ideologia revolucionária solapadora das monarquias absolutas, a Lei Orgânica da nova república era um projeto superior em substância e qualidade à "Súplica" portuguesa de 1808.

Com efeito, o Governo Provisório da República de Pernambuco decretava em março de 1817 aquela lei constante de 28 artigos e que tinha todas as características de um ato constituinte provisório, semelhante na essência ao decreto $\mathrm{n}^{\circ} 1$ de 15 de novembro de 1889 , mediante o qual se decretou a queda do Império, a instituição da República, o fim do Estado unitário, o advento da Federação e a criação da forma presidencial de Governo.

As Bases pernambucanas antecederam em quatro anos àquelas lançadas em 9 de março de 1821, em Lisboa pelos constituintes "vintistas" de Portugal. Foram formuladas já com o selo de legitimidade da soberania popular, expressamente invocado no texto revolucionário.

Com efeito, o documento de 1817 consagrava fórmulas avançadas de organização do poder, vazadas na doutrina do povo soberano, na convocação de uma constituinte, na tolerância de todas as seitas cristãs, posto que estabelecesse o catolicismo romano por religião do Estado, na proibição de atos de perseguição por motivos de consciência, na garantia e estabilidade da magistratura, na proclamação da liberdade de imprensa, no chamamento à responsabilidade dos governantes cujos atos minassem a soberania do povo e os direitos do homem, equivalente portanto ao instituto que na forma presidencial de governo tomou a designação de impeachment, na criação de um Colégio Supremo de Justiça e finalmente no reconhecimento inferido do art. 28 de que a Assembléia Constituinte é a sede do poder legítimo delegado pelo povo.

Tratava-se de um projeto da lavra de Antônio Carlos proposto por instrumento de Governo aos revolucionários de Pernambuco de 1817, e que aparecia no mesmo ano da malograda conspiração de Gomes Freire de Andrade em Portugal à frente de conjurados liberais, todos imolados pela sentença capital do absolutismo.

A Reação triunfara tanto no Brasil quanto em Portugal frente aos sucessos daquele ano. Mas as forças que então sucumbiram às armas do status quo desde logo renasceriam dos dois lados do Atlântico conduzidas pelo mesmo pensamento constitucional de limitação da autoridade governativa: lá, com os civis e militares do Sinédrio, que prepararam a revo- 
lução do Porto de 24 de agosto de 1820, a qual, vitoriosa, teve em 1821 o seu coroamento liberal consubstanciado na convocação e instalação das Cortes de Lisboa; aqui, com o decreto do Príncipe Regente de 3 de junho de 1822, que convocava a "Assembléia Geral Brasílica e Constituinte e Legislativa"; meses antes, portanto, que D. Pedro I, às margens do Ipiranga, proferisse, segundo o testemunho da historiografia tradicional, o seu célebre grito de Independência ou Morte, do dia 7 de setembro daquele ano, depois convertido em data comemorativa da nossa emancipação política.

A Constituinte convocada em 22 e instalada em 23 era a fronteira que realmente separava politicamente o nosso destino do de Portugal, rompendo as derradeiras esperanças de estabelecer a comunhão constitucional dos dois Reinos. Esta poderia dantes ter resultado da tarefa constituinte das Cortes de Lisboa, não fora a cegueira reacionária de sua maioria, cujo comportamento hostil ao Brasil ficou patente numa série de decretos, cujo propósito se cifrava em reduzir o grau de nossa autonomia.

A linguagem do decreto de 24 de abril de 1821, por exemplo, arrogante, capciosa e ambígua, inculcava uma retroação colonialista; já não falava em Reino Unido, mas em Províncias Ultramarinas e Estados Portugueses de Ultramar, ao mesmo passo que parecia atentar contra a política de aglutinação do Príncipe Regente, cuja autoridade buscava desconsiderar ou enfraquecer.

Assim é que outro decreto de 30 de setembro de 1821 sujeitava diretamente à autoridade das Cortes os governadores e comandantes de armas das Províncias e, finalmente, o decreto de 12 de janeiro de 1822 , extinguia os tribunais criados no Brasil por D. João VI cassando a autonomia judicial do Reino.

Todos esses atos faziam cada vez mais tensas as relações com a Regência, que já não se submetia às medidas de arbítrio provenientes de Portugal e suas Cortes.

Enquanto isso se passava, nas Cortes mesmas, a deputação brasileira forcejava por trilhar os caminhos da união constitucional, ainda depois do escândalo e da indignação provocada pela Representação da Junta de São Paulo de 24 de dezembro de 1821 dirigida ao Príncipe Regente, protestando com toda veemência contra a política de asfixiante centralização levada a cabo pelas Cortes e ao mesmo passo conclamando o Príncipe a não acatar as ordens de retorno a Portugal, como fora determinado por aquela assembléia, obtendo a célebre resposta afirmativa do "Fico". 
Os ânimos das Cortes ficaram ainda mais exacerbados depois que o padre Diogo Antônio Feijó, futuro Regente do Império, na sessão de 25 de abril de 1822 fez a sua célebre Indicação, movido do propósito de "consolidar a reunião da grande família portuguesa". Entre outros pontos propunha que o Congresso de Portugal declarasse o reconhecimento da Independência de cada uma das Províncias do Brasil, enquanto não se organizasse a Constituição e que esta obrigaria somente aquelas Províncias cujos deputados "nela" concordassem pela pluralidade de seus votos.

Vejamos como as Cortes e a deputação brasileira em Lisboa reagiram aos dois documentos.

As Cortes viram na Representação da Junta de São Paulo, endereçada ao Príncipe Regente e subscrita, entre outras figuras de relevo, por José Bonifácio de Andrada e Silva, um ato de rebeldia e ofensa à Regeneração Política de Portugal, tanto que propuseram a abertura de processo contra os membros da Junta. Ao mesmo, num recuo aparente, concordavam com a permanência de D. Pedro no Brasil "até a publicação do Ato Adicional, governando, porém, com sujeição às Cortes" (Viveiros de Castro, Memórias, apresentada ao Primeiro Congresso de História Nacional. Rio de Janeiro, 1914, p. 94).

No plenário do "Soberano Congresso" ecoavam protestos como os de Fernandes Thomaz, futuro ministro liberal, de grande renome, e deputado pela Beira, ou de Francisco Xavier Monteiro, deputado pela Extremadura; o primeiro com moderação e ironia, mas um tanto resignado diante da separação iminente, asseverava: "passe o Sr. Brasil muito bem, que nós cá cuidaremos de nossa vida", ao passo que o segundo, demonstrando maior exaltação de ânimo, instava por salvar a dignidade nacional embora se perdessem dez Brasis" (Gomes de Carvalho, apud A.O. Viveiros de Castro, ob.cit., p. 94).

Alguns deputados brasileiros, surpreendidos talvez pelos termos um tanto passionais da Representação, foram cautelosos na sua reação ao documento da Junta, todavia cingindo-se a condenar os excessos de linguagem contra uma assembléia que ainda lhes merecia respeito por ser órgão do princípio mais avançado da época, a saber, o da soberania popular. Provavelmente por alimentarem a tênue e vaga esperança de restaurar a confiança nas Cortes como assembléia constituinte, capaz de elaborar e executar um projeto de união constitucional dos dois Reinos cuja separação já se lhes afigurava iminente. Ocuparam então a tribuna constituinte num tom conciliatório os deputados Gonçalves Ledo, Campos Vergueiro, Pinto de França e Almeida e Castro, que viam contudo esmaecer a possibilidade de reconci- 
liar as Cortes com um Príncipe que lhes recusava obediência e súditos que aliados a ele engrossavam as hostes dissidentes.

Quanto ao segundo documento - a Indicação de Feijó - as Cortes reagiram com a mesma indignação, não tendo sido sequer submetido a debate e, por determinação do Presidente, o Conselheiro Fortes, remetido a uma Comissão de Negócios Políticos onde ficou engavetada ou "sepultada", consoante relata Viveiros de Castro em sua Memória (Viveiros, ob.cit., p. 99-100).

A Indicação de Feijó também repercutiu entre seus colegas da bancada constituinte do Brasil que, sem embargo da tensão produzida por aquela propositura, não arrefeceram, diante de tanta relutância e malevolência das Cortes, em insistir na obra comum de uma Constituição que salvasse a unidade política luso-brasileira.

Movendo-se nesse sentido, em 15 de junho de 1822, Fernandes Pinheiro, Antônio Carlos, Vilela Barbosa e Araújo Lima introduziam no "Soberano Colégio" um Projeto de Artigos Adicionais à Constituição portuguesa constante de 15 artigos, no qual propunham, entre outras medidas de largo alcance, a existência de dois Congressos: um no Reino do Brasil, outro no de Portugal e Algarve, ambos compostos de representantes eleitos pelo povo na forma que a Constituição determinasse. "Tocante à sede do Congresso Brasileiro, ficaria na capital onde o Regente do Reino residia enquanto não se fundasse no Centro do Brasil uma nova Capital".

Além dos Congressos das Cortes especiais, haveria as Cortes Gerais de toda a Nação que se reuniriam na Capital do Império Luso-Brasiliano. Instituía no Reino do Brasil um tribunal supremo de justiça e prescrevia que "as províncias da Ásia e da África Portuguesa declarariam a que Reino queriam incorporar-se para terem parte na respectiva representação do Reino a que se unissem".

O Projeto de Artigos Adicionais à Constituição elaborado pela Comissão Brasileira era o ato final da batalha da bancada constituinte brasileira que passara à ofensiva derradeira em seus esforços de manter a união dos Reinos, cada vez mais ameaçada e comprometida pela intransigência passional das Cortes.

Coube ao deputado de Trás-os-Montes, Ferreira Girão, fulminar o projeto em termos incandescentes: "Não é possível que o sangue deixe de ferver nas veias dos lusitanos perante um projeto que não ouso qualificar em consideração aos seus autores" (Viveiros de Castro, ob. cit., p. 85). 
Teve o Projeto uma tramitação penosa e tumultuada. Houve solicitação de novo projeto e quando as Cortes o puseram em discussão na sessão de 7 de agosto de 1822, o deputado Girão, segundo refere Aurelino Leal, pediu o adiamento do debate, até que chegassem informações mais precisas acerca dos sucessos no Rio de Janeiro (A. Leal, História Constitucional do Brasil, Rio de Janeiro, Imprensa Nacional, 1915, p. 47). Antônio Carlos requereu a declaração de vacância dos lugares da deputação brasileira às Cortes, ao perceber a inutilidade da nossa presença ali. O "Soberano Congresso" indeferiu-lhe o pedido, mas não pôde prevenir o colapso da tarefa de unificação constitucional que a nossa presença ali afiançava.

Os fatos subseqüentes compendiavam o fim daquela projetada aliança fundamental dos dois Reinos: a fuga de sete deputados brasileiros trasladados à Inglaterra, onde em Falmouth expediram o célebre manifesto de 6 de outubro de 1822 dando a Portugal e ao mundo "os motivos que os obrigaram a assim obrar", e a promulgação em 23 de setembro de 1822 da primeira Constituição de Portugal pelas Cortes Extraordinárias e Constituintes da Nação, decretada "em nome da Santíssima e Indivisível Trindade".

Debaixo de coação, 36 deputados brasileiros fizeram ali constar as suas assinaturas. Viveiros de Castro relata nestes termos a insólita ocorrência: "Por escrúpulos de consciência, eles, os representantes das províncias que se libertavam do jugo da Metrópole, não queriam jurar nem assinar a Constituição; as Cortes, porém, não consentiram nesse ato de rebeldia e quase todos os deputados brasileiros cumpriram a aludida formalidade, convencidos de que não havia perjúrio sendo ato praticado sob coação" (Viveiros, ob.cit., p.102-103).

A primeira constituinte brasileira foi portanto aquela que se incorporou com a nossa deputação nas Cortes de Lisboa, onde deveria desempenhar a tarefa de escrever a Lei Fundamental de União dos dois Reinos. Constituinte, como vimos, malograda, invalidada e esmagada pelos ditames decisórios provenientes do peso majoritário que fazia onipotente a parcela maior da representação constituinte, formada por deputados portugueses, desfigurando-se assim, desde o começo, a presença e eficácia participativa da nossa bancada. Esta ficava por sua inferioridade numérica incapacitada de exercitar influxos sobre os rumos a serem seguidos por aquele colégio constituinte.

Ali a voz dos deputados constituintes do Brasil, pouca ou nenhuma importância teve na elaboração da Carta; em verdade foram compelidos a subscrever a Lei Maior das Cortes, depois de assistirem à rejeição aniquilante de suas Propostas e Projetos, designadamente aqueles nos quais se resguar- 
dava o interesse da nova nacionalidade que irreprimivelmente se formou à sombra do Reino Unido e que procurava, a partir daquele momento de decepção, seguir, como seguiu, a via autônoma de sua própria legitimidade constituinte.

Em suma, nas Cortes de Lisboa o poder constituinte se repartia entre as deputações portuguesa e brasileira, mas o predomínio absoluto da primeira ofuscou, refreou, dominou e inibiu a segunda, que ali desempenhava basicamente função decorativa, colegitimando com sua presença decisões que até mesmo na esfera de interesses mais peculiares e diretos do Brasil lhe eram subtraídas, não podendo assim ter sobre elas eficácia ou jurisdição.

Ao mesmo passo que em Lisboa se sufocara a ação constituinte participativa dos deputados brasileiros, no Rio de Janeiro o quadro não era menos dificultoso, atropelado e entregue às incertezas de um meio político convulsivo, onde também se jogava o destino do Reino Unido e ocorriam episódios extremamente graves para o futuro da Coroa portuguesa.

Não perceberam as Cortes que uma nova nacionalidade nascia do grande parto liberal da monarquia portuguesa consorciada ao elemento nativo, cuja busca de identidade e independência tinha raízes nas lutas coloniais de expulsão dos invasores, passava pela Inconfidência e subia de ponto nos sucessos da Revolução Pernambucana de 1817 até chegar ao momento culminante da Assembléia Nacional Constituinte.

É aí que se nos depara a intervenção simultânea de dois poderes constituintes, cujas relações foram sempre marcadas de indissimulável tensão, de teor competitivo, e perpassadas de mútuos ressentimentos, disputas de supremacia e recíprocas desconfianças, acabando assim por inaugurar uma crise constituinte da qual nunca nos libertamos por inteiro senão de maneira aparente, ocasional e fugaz, mais na aparência que na realidade.

Recidiva ao longo de nossa história constitucional, tal crise se assemelha a um vulcão, ora adormecido, ora em erupção, deitando não raro sua lava fumegante sobre as instituições, e calcinando os edifícios do Império e da República em distintas épocas constitucionais e políticas do passado.

Chegou aos nossos dias como um fantasma que ronda a democracia, o sistema representativo, a separação de poderes.

Quais foram esses dois poderes constituintes?

O poder constituinte originário, dos governados, teve a sua soberania golpeada e embargada, não sendo portanto partícipe da obra criadora das nossas primeiras instituições públicas, como Estado e Nação; e o poder consti- 
tuinte derivado do absolutismo, o poder constituinte do príncipe que fez a Carta Imperial; ao invés da promulgação, uma outorga; ao invés do ato de soberania de um colégio constituinte, o mesmo ato por obra da vontade e do livre arbítrio de um imperador, que na Carta Fundamental decretara a autolimitação de seus poderes.

Em nenhum outro país da América Latina houve semelhante ato de poder. Ali as constituintes fundaram repúblicas; aqui, nesta parte do continente, a constituinte não pôde cumprir sua tarefa, dissolvida que foi pelo Golpe de Estado de 1823. Houve tão somente a metamorfose de uma monarquia absoluta em monarquia constitucional, abrangendo esta ao longo de sua trajetória o Primeiro Reinado, a Regência e o Segundo Reinado; três épocas políticas que marcaram o Império sob a égide da Constituição outorgada, a célebre Carta de 1824.

Durante a fase constitucional do Império inexistiu o controle de constitucionalidade. Em rigor, a Constituição era unicamente na essência a carta programática dos direitos da primeira geração e do princípio da divisão de poderes. Demais disso, a sua flexibilidade escusava grandemente a adoção daquele controle.

Três originalidades teve porém o documento produzido pelos juristas do Conselho de Estado e que se transformou na célebre Carta política do Império, outorgada por D. Pedro I e depois trasladada para Portugal com modificações do próprio punho do Imperador, após abdicar o trono português, em favor de sua filha menor, D. Maria da Glória, a primeira rainha constitucional de Portugal. Foi assim que surgiu a Carta de 1826, símbolo e ícone do constitucionalismo português, na estréia de seu confronto e subseqüente consolidação frente à cruenta reação dos miguelistas fratricidas, empenhados em restaurar a coroa do absolutismo e fazer outra vez vivas as instituições peremptas do passado e dos privilégios consagrados.

A primeira originalidade residiu na Carta de direitos e na enunciação de deveres. A segunda consistiu em estabelecer com relevância hierárquica superior a constitucionalidade material, definida com extrema clareza e tornada juridicamente de teor mais significativo que a constitucionalidade formal. A terceira esteve na criação de um quarto Poder, concebido primeiro na esfera teórica e importado de pensadores ou juristas franceses, desde Clermond Ferrand a Benjamin Constant.

Teve esse quarto Poder pela vez primeira no mundo das Constituições, segundo é de nosso conhecimento, o seu ingresso na Carta Política do Império. Tudo por obra das circunstâncias, associadas a um perfil de 
personalidade, tornando-se em seguida a mais venturosa de todas as inovações políticas e constitucionais que ornaram a autoridade imperial durante o Segundo Reinado da monarquia brasileira.

Nossa primeira "ditadura constitucional” ocorreu ao alvorecer do Império. Foi obra do Poder Moderador, configurando, em verdade, um estranho paradoxo, do ponto de vista teórico, porquanto veio a ser exercitada precisamente por aquele Poder que havia sido concebido, teoricamente, pelo menos, como uma espécie de corregedoria dos três ramos em que se divide o exercício da soberania nacional (executivo, legislativo e judiciário).

O pensamento central de seu autor - o publicista Constant - era fazêlo uma espécie de poder judiciário dos demais poderes, investido claramente nessa tarefa corretiva para pôr cobro às exorbitâncias e aos abusos suscetíveis de abalar a unidade política do sistema. Mas tanto na letra constitucional como na execução, os políticos do império lhe desvirtuaram o sentido e a aplicação.

Desvirtuaram-lhe o sentido, quando o consubstanciam em artigo da Carta como profissão de fé política e normativa de uma concentração de poderes sem paralelo na história dos países hemisféricos, que se constitucionalizaram à sombra dos dogmas da Revolução Francesa ou dos postulados da Revolução Americana. Basta ver a extensão de poderes conferidos a seu titular no art. 101 da Constituição Imperial de 25 de março de 1824.

Desvirtuaram-lhe por igual a aplicação, quando o primeiro Imperador o exercitou em termos absolutos de exceção. Feriu ele desse modo o espírito da Carta, sobretudo a legalidade e a constitucionalidade do regime, ao fazer das Comissões Militares o instrumento repressivo, por excelência, das agitações anti-imperiais e que impopularizou o monarca nas províncias do Nordeste e do extremo Sul. Tudo isso precedeu as manifestações populares mais agudas e ostensivas ocorridas em solo mineiro, e que tiveram por desfecho o ato da Abdicação.

Demais disso, o Poder Moderador era a programação deliberada da ditadura porquanto contrariava a regra substantiva de Montesquieu da divisão e limitação de poderes.

Com efeito, a Carta enfeixava numa só pessoa - o Imperador - a titularidade e o exercício de dois Poderes. De tal sorte que a Lei Maior criava assim um monstro constitucional. Não criava um órgão legítimo, distinto e capacitado, como seria de sua vocação, a promover a harmonia e o equilíbrio dos Poderes; um órgão que pudera ter sido - e nele lhe vislumbramos essa virtude ou possibilidade - o germe de uma espécie de judicatura políti- 
ca, capaz de antecipar na práxis e na teoria, por sua ação, preventiva de controle de conflitos, os tribunais constitucionais a quem o século seguinte entregaria os freios de constitucionalidade.

Desse objetivo porém nos acercamos depois confusamente por intuição teórica. Basta para tanto refletirmos a fundo acerca do alcance daquela embrionária instituição preconizada por Constant, enquanto fórmula expansiva e aperfeiçoadora, construída sobre os alicerces da obra e do gênio de Montesquieu.

Feitas estas ponderações respeitantes ao regime da Carta outorgada de 1824 , cabe assinalar o seguinte:

O constitucionalismo brasileiro do século XX é tão caracterizadamente republicano quanto o do século XIX, que já examinamos, fora imperial. Aliás este se viu marcado por uma única Constituição - a de 1824 - obra da outorga do Imperador e que regeu o país até 15 de novembro de 1889, quando se deu a queda do Império, e o advento de um novo sistema institucional proclamado naquela data. Graças a esse sistema instalou-se a república e a federação, constantes do Decreto $\mathrm{n}^{\circ} \mathrm{l}$ do Governo Provisório, cujos membros assumiram os encargos imediatos da nova ordem estabelecida sobre as ruínas da monarquia deposta.

Após um interregno ditatório de dois anos, restabeleceu-se a normalidade constitucional do regime político mediante a promulgação do primeiro Estatuto Fundamental da República.

Estreia-se desse modo o primeiro período do constitucionalismo republicano, que vai perdurar de 1891 a 1930, assinalado, de início, por profundas transformações em relação ao sistema decaído e sem as quais não se lograria a consolidação do poder recém inaugurado.

Com efeito, a primeira dessas mudanças, de inspiração americana, cifrou-se na adoção do modelo federativo, pelo qual Rui Barbosa com ardente empenho se batera em vão durante os derradeiros anos do Segundo Reinado.

A campanha malograda por uma monarquia federativa atuou decisivamente no ânimo de Rui para convertê-lo, de última hora, em adepto da causa republicana, cuja pregação não constava aliás dos seus escritos políticos estampados na imprensa às vésperas do movimento que derrubou a monarquia. E o mais singular é que este insigne homem público se tornou de repente a cabeça pensante da república, o arquiteto das novas instituições, o criador da fórmula que seu decreto antecipara e logo foi consagrado 
pela Constituição de 1891, da qual, como se sabe, e já se provou inequivocamente por via documental, fora ele o principal artífice. Das suas luzes e das suas idéias nasceu aquela Carta do Brasil republicano, federativo, presidencialista, arredado da tradição européia e acercado ao influxo norteamericano, em cuja órbita gira até hoje sob a égide de um presidencialismo constitucional.

As alterações da segunda Constituição brasileira com respeito à Carta outorgada de 1824 foram portanto a introdução da república, da federação e da forma presidencial de governo.

A evolução constitucional do país patenteia que nessas três espécies políticas o progresso qualitativo se apresentou basicamente nulo durante o primeiro período republicano, cujas turbações mais de uma vez puseram o regime à beira da ruptura.

Com efeito, as três inovações fundamentais levadas a cabo por inspiração do constitucionalismo norte-americano, cuja excelência Rui professava com ardor, foram de certa maneira decepcionantes e mais uma vez puseram em contraste a diferença da forma à matéria, da idéia à realidade, da teoria à prática.

A república em si mesma não penetrara ainda a consciência da elite governante e da camada social hegemônica, talvez à míngua de preparação, porquanto no diagrama do novo regime os fatos atropelaram os valores; os interesses sobrepujaram as idéias; a destemperança, as vaidades e a soberba calcaram as verdades; as paixões, as ambições e os ódios escureceram o bom senso e a razão. Disso promanou a ditadura militar de Floriano que Rui tanto exprobrou e da qual veio a ser, sem dúvida, a principal vítima.

A solução republicana, ministrada de surpresa, não estava ainda por inteiro presente nem amadurecida no espírito público e no domínio da opinião. $\mathrm{O}$ ato institucional de 15 de novembro, se não fora as ditaduras de Deodoro e Floriano e a fereza da repressão, segundo escreviam na época os opositores da monarquia, não teria vingado.

É de recordar que Rui mesmo deixara aberta no decreto $n^{\circ} 1$ a porta plebiscitária de um eventual retorno ao regime decaído. Essa porta foi fechada dois anos depois pela Constituição de $1891 \mathrm{em}$ termos definitivos.

Tocante à federação, o sistema logo manifestou na aplicação as suas fraquezas, as suas imperfeições, os seus erros, distanciando-se, por completo, do original norte-americano, de que fora cópia servil. 
Durante décadas perdurou a instabilidade, a tensão, a crise, a animosidade, o desequilíbrio nas relações entre a União e os corpos federados. O despreparo destes para o exercício das competências federativas manifestava-se patente, ocasionando assim um quadro político deveras turbulento, marcado por abusos, extravios de poder, intervenções federais e freqüente decretação de estados de sítio, fontes portanto de violência e desrespeito contumaz e descarado à liberdade e às competências constitucionais dos entes políticos da federação.

Toda a nossa evolução constitucional, já ao longo do Império, já ao longo da República é entrecortada de crises e rupturas. Não é, como se poderia cuidar à primeira vista, uma evolução tranqüila, isenta das tormentas de sangue e violência que se estamparam na crônica de outros povos e nações.

Foi perpassada sempre de grave crise e essa crise chega aos nossos dias, qualificada, com inteira razão, de crise constituinte porque é crise das instituições e da Constituição; não é como seria normal crise na Constituição ou crise meramente constitucional, conforme temos em outras ocasiões assinalado com reiterada freqüência.

A Carta do Império, outorgada sobre as ruínas de uma constituinte dissolvida, nasceu debaixo dos protestos constitucionais dos revoltosos da Confederação do Equador, sob o signo da desconfiança e da suspeita de uma restauração absolutista.

Mas por um acaso histórico das circunstâncias, aquilo que tinha tudo de negativo para ser um desastre constitucional, como aliás foi no Primeiro Reinado, prosperou e floresceu depois da Regência durante o Segundo Reinado por obra e temperamento de um rei ilustrado, sábio e prudente que foi D. Pedro II.

Estamos nos referindo ao Poder Moderador, cujo titular, o monarca, enfeixava ilimitadas competências, exaradas nos artigos da Carta, e todavia se houve com extremo zelo, afastando-se da sedução daquele círculo de autoridade verdadeiramente absoluta que a contradição da Lei Fundamental do Império lhe depositara nas mãos. E, mediante o abrandamento do poder pessoal, fez possível vingar no país um projeto representativo e parlamentar de poder consentido e compartilhado, de inspiração inglesa.

Foi esta, sem dúvida, uma das máximas originalidades da época imperial de nossa História. Modelo aliás deploravelmente atropelado e aniquilado pelo Golpe de Estado republicano, o qual operou uma reviravolta das nossas instituições. 
Com efeito, derrubado o Império, Rui Barbosa inaugurou outro farol político e constitucional, aquele do modelo americano, estabelecido pelos fundadores da União Americana. Ergueram os constituintes de Filadélfia o edifício de uma Constituição republicana, presidencialista e federativa. Dela fizemos o traslado numa cópia que serviu tão somente para prolongar ou perpetuar a nossa crise constituinte.

Trocamos o trono inglês pelo Capitólio americano. Troca tão malfeita e tão desastrada que a substituição nada acrescentou de útil ou proveitoso ao aperfeiçoamento da cidadania e à qualidade política das elites cuja decadência ficou patente até chegarem à ingovernabilidade destes dias.

Épocas de federalismo autoritário - uma contradição política em termos - ocorreram no país e oscilaram, durante a Primeira República, da frouxidão dos laços federativos ao extremo arrocho das intervenções centralizadoras, cujo unitarismo contravinha a índole do regime.

Demais disso, o quadro social e político das antigas províncias imperiais, erigidas de repente ao status da autonomia federativa, era sobremodo traçado pela força incontrastável dos oligarcas e coronéis que formavam o patronato do poder e recebiam da autoridade central a sagração de sua ascendência na esfera local de governo.

A primeira Constituição republicana foi na aparência, pelo aspecto formal, a mais estável das Constituições do sistema inaugurado em 15 de novembro de 1889.

Durou 39 anos e passou por uma única reforma que aliás veio demasiado tardia, não podendo conjurar o seu colapso na sucessão do presidente Washington Luís, em 1930. Mas a evidência histórica de uma estabilidade que acabamos de referir era de teor apenas aparente, não disfarçando a república constitucional deveras violenta. Com efeito, a violência se instalou com a ditadura de Floriano, quando a república correu o risco de soçobrar e prosseguiu dissimulada nas comoções políticas ligadas à sucessão dos governos presidenciais.

Aqui entra a figura do presidencialismo, a terceira inovação do regime estabelecido pela Carta de 1891. Presidencialismo que tem sido talvez a peça-chave da crise estrutural do sistema. Em verdade, uma das ocasiões mais significativas em que essa crise penetrou a consciência da nação ocorreu com o deflagrar da Campanha Civilista, promovida e chefiada por Rui Barbosa. Valeu como uma cruzada de regeneração dos costumes políticos, até então atados aos vícios de um presidencialismo militarista, deformador da imagem das instituições e que lhes retirava toda a legitimidade. 
O mesmo sentido teve depois a Reação Republicana de Nilo Peçanha, bem como as sublevações dos dois 5 de julho da década de 20 e, por derradeiro, culminando o processo, o movimento da Aliança Liberal, a chamada Revolução de 30. Com esta selou-se o destino da Primeira República cujas paredes desabaram, carcomidas na falsidade ideológica das atas eleitorais, suprema e afrontosa contradição da representatividade constitucional do regime.

Uma tempestade política e ideológica, acompanhada de fortes abalos na ordem institucional marcou, a seguir, a década de 30 no século XX. Foi a década mais autoritária da primeira metade dos novecentos. Ficou assinalada do mesmo passo por uma invasão de idéias novas e projetos e fórmulas de mudança, ilustrativas do quadro de instabilidade e efervescência, que teve forte repercussão sobre a índole do ordenamento. Sua tonalidade social, bem distinta das cores do sistema decaído, dava a medida das preocupações transformadoras ínsitas aos titulares do poder emergente.

A cognominada Revolução de 30 significou dessa maneira o ponto de partida e a base de apoio de um ambicioso programa de renovação dos costumes políticos, cujo objetivo maior era o estabelecimento da verdade eleitoral, pressuposto de uma ordem representativa mais legítima, em correspondência com o sentimento nacional vigente.

Depois da escravidão, representou o momento em que o país mais sentiu o peso das injustiças sociais e buscou aparelhar-se para ter seu ingresso na era industrial, valendo-se de instrumentos legais aptos a mitigar as proporções do iminente conflito do trabalho com o capital.

Do ponto de vista político, é de ponderar que a ditadura instalada pelo segundo governo provisório republicano em 1930 durou quatro anos e manifestou desde o começo certo pendor continuísta alimentado pelo seu chefe, cujos desígnios nesse sentido foram embargados por uma corrente empenhada em restaurar, o mais breve possível, a ordem constitucional suspensa desde aquele ano.

Desse movimento de resistência nasceu a malograda Revolução Constitucionalista de 1932, em São Paulo. A derrota militar dos revoltosos em nada obstou porém o triunfo da causa, logo concretizada e consagrada com o ato convocatório da Constituinte de 1933. Daí resultou logo depois a promulgação da Carta de 1934.

Fechado o interregno ditatório de quatro anos, a Constituição de 1934 inaugurou a Segunda República. Teve ela contudo breve e precária existência porquanto promanara de uma ambiência política marcada por mutila- 
ções participativas, crises, desafios, suspeitas, incertezas, contestações e ressentimentos.

A Constituinte que a promulgou não auferiu a necessária densidade legitimante que é de exigir de um colégio de soberania. As lideranças do ancien régime republicano permaneciam no exílio político, afastadas de toda participação. As forças políticas situacionistas, por sua vez, elegeram presidente da República, por via indireta, o ex-ditador e chefe revolucionário do movimento de outubro de 30, um homem cujo apetite pelo poder o levou, três anos, depois a desferir o golpe de Estado de 10 de novembro de 1937.

O novo interregno republicano de normalidade constitucional ocorreu tão somente na aparência, sobretudo a partir de novembro de 1935, quando rebentaram as quarteladas comunistas do Rio de Janeiro, Natal e Recife, cuja eclosão sobressaltou o país e intimidou as camadas sociais do coronelismo rural e da burguesia urbana ascendente.

A repressão feita, cifrada na Lei de Segurança, no estado de guerra e no Tribunal de Segurança Nacional e nas pressões sobre as duas Casas do Congresso, processando deputados e senadores e expurgando das fileiras militares e civis da sociedade personalidades suspeitas ao regime, vaticinava já o desfecho trágico do golpe de 1937. Este se consumou às vésperas da eleição presidencial direta em que concorriam ao poder as candidaturas de José Américo de Almeida e Armando Sales de Oliveira, o primeiro candidato do Governo, o segundo da Oposição, ambos porém vítimas do braço golpista que inaugurou no país a ditadura do Estado Novo.

À frente desta, Vargas governou o Brasil sem dar sequer execução à própria Carta que outorgou, a célebre "polaca" de autoria do jurista mineiro Francisco Campos.

O regime de exceção caiu em 29 de outubro de 1945, por um golpe militar inspirado no sentimento de redemocratização que se enraizara na consciência nacional ao longo dos anos da presença brasileira na Segunda Guerra Mundial, quando efetivos da Força Expedicionária Brasileira foram aos campos de batalha da Itália enfrentar os exércitos da aliança totalitária do fascismo e do nacional-socialismo.

Pôs-se termo assim a uma flagrante contradição política e ideológica que era a sobrevivência do Estado Novo, de bases ditatoriais, num mundo que emergia das ruínas da guerra, fizera vitoriosa a causa das velhas democracias liberais e passara a reconstruir o contrato social, escrevendo em São Francisco, em 1945, a Carta das Nações Unidas, logo seguida, em dezembro de 1948, da Declaração Universal dos Direitos do Homem. 
A Constituição de 18 de setembro de 1946, com seus 218 artigos e 36 disposições transitórias, representou um compromisso das correntes conservadoras da velha tradição republicana e representativa de $1891 \mathrm{com}$ as forças remanescentes do radicalismo liberal de 30 . Sobretudo com a facção congressualmente majoritária que provinha do Estado Novo e ressentida ainda com a deposição de seu ditador e o desmantelamento de sua máquina política, ganhara, todavia, contra todas as expectativas, a eleição de 2 de dezembro de 1945. Essa facção conservadora, formada nos quadros da ditadura, mostrava-se disposta a manter sua hegemonia governativa nos moldes da Lei Magna recém-promulgada.

As pressões ideológicas da década já não eram contudo tão fortes e os constituintes de 46 lograram escrever uma Constituição com pontos significativamente positivos. Constituição que traduzia equilíbrio e bom senso para as circunstâncias da época, pôde ela atenuar e fazer latente e adormecida durante largos anos de sua vigência o vulcão da crise constituinte, cujas erupções não vieram tão imediatas e de súbito como as que implodiram a Constituição de 1934.

Sem revogar o Estado social do texto efêmero da primeira reconstitucionalização, a Carta de 46 ficou limitada aos termos programáticos de justiça social, não podendo concretizar cláusulas como aquelas que determinavam a participação do trabalhador nos lucros da empresa nem tantas outras exaradas na esfera das relações do capital com o trabalho.

As comoções políticas de raiz social fizeram-na desembocar, por obra da corrupção do regime presidencial, na segunda ditadura do século, a mais longa e perniciosa por haver mantido aberto um Congresso fantoche, debaixo de uma Constituição de fachada outorgada pelo sistema autoritário, que ao mesmo tempo censurava a imprensa e reprimia a formação, pelo debate livre, de novas lideranças, sacrificando assim toda uma geração. Tal aconteceu em 1964 quando o país atravessou durante duas décadas a mais sombria ditadura militar de sua história.

Com a Constituição de 1988 e ligeiras observações acerca da crise em que ela se acha imersa, poremos o ponto final a este despretensioso relato da evolução constitucional do Brasil.

A Constituição de 1988, ao revés do que dizem os seus inimigos, foi a melhor das Constituições brasileiras de todas as nossas épocas constitucionais. Onde ela mais avança é onde o Governo mais intenta retrogradá-la. Como constituição dos direitos fundamentais e da proteção jurídica da Sociedade, combinando assim defesa do corpo social e tutela dos direitos subjetivos, ela fez nesse prisma judicial do regime significativo avanço. 
Fez, por exemplo, do Supremo Tribunal Federal taxativamente um tribunal de guarda da Constituição. Mas ele nesse ponto se autodemitiu da importantíssima e crucial tarefa de concretizar nas controvérsias do sistema, onde as bases da democracia constitucional estavam em jogo, a sua missão protetora de salvaguarda das instituições. Os que ora desfecham um golpe de Estado institucional não são portanto molestados pela Justiça constitucional: e permanecem intangíveis, fora do alcance do braço da Lei Suprema, pervertendo, afrontando e despedaçando, cada vez mais, as instituições do país.

Com referência a outro ramo de sustentação da ordem republicana e democrática, a mesma Corte fez vista grossa ao poder que mais pode e que em verdade é o motor constitucional dos demais poderes, atrelando-os às suas irresponsabilidades legislativas e aos seus atentados desrespeitos e desmoralização de decisões judiciais, ostensivamente descumpridas. Aniquilam-se assim por obra do Executivo as bases éticas e jurídicas do sistema. E onde tal acontece, há ditadura, e não há governo. Há despotismo, e não há Constituição. Há obediência, e não há consenso. Há legalidade, e não há legitimidade. E a legalidade que há é todavia a força, que enfraquece a dignidade da pessoa humana, a justiça dos direitos sociais, a sobrevivência da democracia, a defesa e proteção do Estado soberano.

Cabe, portanto, na seqüência dessas reflexões, fazer esta tríplice indagação:

Até quando a Amazônia permanecerá exposta às lesões da soberania nacional?

Até quando a política ingovernável governará a república?

Até quando o síndico da massa falida no poder liquidará as contas do patrimônio público cifradas nas privatizações alienadoras da riqueza nacional?

São três indagações cruciais que comprometem todos os princípios de sustentação e legitimidade constitucional pertinentes à república criada pela Constituição de 1988.

O ordenamento jurídico vem sendo destroçado em grande parte pelo golpe de Estado institucional desferido por meio de Medidas Provisórias que expulsam do exercício do poder legítimo os dois órgãos paralelos da soberania nacional, o Legislativo e o Judiciário. E assim o governo, sem dar satisfação ao povo, à opinião, ao país e à sociedade, executa a implacável política da recolonização. 
Aqui termina, minhas senhoras e meus senhores, a evolução constitucional do Brasil; termina com as omissões da falsa elite representativa, cúmplice silenciosa dos atos que destróem a democracia e o regime. Mas não termina aí a luta do povo brasileiro. A alvorada da democracia participativa se desenha nas linhas do horizonte político e esparge luz sobre as esferas teóricas nas quais se constrói um novo constitucionalismo de luta e resistência, abraçado com o povo, com a cidadania, com as atas da Inconfidência, com a memória da Confederação do Equador, com a campanha abolicionista de Castro Alves, Nabuco e Rui Barbosa, com as Diretas-Já e com as jornadas do impeachment que ontem mostraram como as lideranças podem sucumbir. O que jamais poderá sucumbir é o povo brasileiro.

Esta assembléia, este auditório, esta academia de letras passam a certidão de que a Nação vive e sobrevive e mantém intacta a consciência de seus valores, com os quais há de forjar as armas do confronto.

O povo, portanto, dirá sim à democracia e não à recolonização. É esta a mensagem dos nossos 500 anos de presença nos fastos da História.

Não volveremos ao passado porque somos o verdadeiro Brasil do ano 2000, o Brasil que está no vosso sentimento constitucional e na vossa alma e vocação de liberdade.

Paulo Bonavides é professor emérito da Universidade Federal do Ceará. É autor de várias obras, entre elas O Partido Político no Império (1956), Estado Liberal ao Estado Social (1958), Ciência Politica (1967), A crise politica brasileira (1969), Discursos parlamentares (1979), Direito Constitucional (1980), Estado e formas de estado e governo (1982), Curso de Direito Constitucional (1994) e Textos politicos da história do Brasil (1996).

Conferência feita pelo autor na Academia Piauense de Letras em 27 de julho de 2000. 